\title{
ASSESING EUROPEAN REASEARCH \& DEVELOPMENT AND INNOVATION POLICIES IN SPAIN FROM A GENDER PERSPECTIVE
}

\author{
Rosario Gómez*, Amelia Sanchis**, Luis A. Palma***
}

\begin{abstract}
Background. Gender Impact Estimation (GIE) reports are an ideal tool to assess European R\&D and innovation policies in Spain from a gender perspective.

Research aims. The primary objective of this study is to further the use of GIE reports as a tool for diagnosing whether a given measure or policy will affect women and men equally. Our secondary objectives are: a) present a gender diagnostic; b) propose measures and policies that will help close the existing gender gap and promote equal opportunities for men and women.

Methodology. Methodologically, this tool will be used to analyse the actions taken by the Seventh Framework Programme and the first Horizon 2020 Programme. We start by analysing the development of gender equality legislation in Spain. The second part of our study adapts GIE reports as a tool for evaluating and diagnosing European research and innovation projects.
\end{abstract}

Key findings. This adaptation is the most important contribution of our study, as it allows for the analysis of public R\&D and innovation policies from a gender perspective. This system may help to create wealth and economic growth, as it allows men and women's contribution to be properly valued from an equal opportunity perspective.

Keywords: innovation policies, gender, GIE.

\section{INTRODUCTION AND BACKGROUND}

Since the 1995 Beijing World Conference, public intervention has taken a more active stance in promoting gender equality. The Platform for Action adopted at this Conference focuses on the key topics which

\footnotetext{
* Rosario Gómez, University of Cordova, Spain. E-mail: rogofi83@hotmail.com

** Amelia Sanchis, University of Cordova, Spain. E-mail: dh1savia@uco.es

*** Luis A. Palma, University of Seville, Spain. E-mail: 1palma@us.es
} 
have been identified as the main obstacles to the empowerment of the world's women. Furthering gender equality benefits the whole society, including the economy. However, data shows that the gender gap still exists. In 2013, Spanish women's yearly average salary was below their male counterparts' in every sector of economic activity (Statistics National Institute, INE, 2013a). While women's yearly average salary was 19,514.58 Euros in 2013, men earned 25,695.17 Euros. A female worker's salaries are only $76 \%$ of what a man earns (INE, 2013b).

Furthermore, the female participation rate remained constant until the 1945 United Nations Charter, which established women's rights as a basic principle. The Universal Declaration of Human Rights (UDHR) of 1948 proclaims that "everyone is entitled to all the rights and freedoms set forth in this Declaration, without distinction of any kind, such as race, color, sex (...)". The 1979 Convention on the Elimination of all Forms of Discrimination against Women (CEFDW) clearly states that women's human rights include all of the civil, political, economic, social, and cultural rights which make up the society's foundation. At the same time, there have been other United Nations Conferences and Summits, such as the 1993 Human Rights Convention in Vienna, which saw violence against women and other matters relative to women's rights integrated into the UN's general activity and agenda (Sanchís, 2015).

After the ratification of the 1978 Spanish Constitution, civil, labour, and penal law were all submitted to a succession of reforms aimed at eliminating gender discrimination from Spain's legal system. In article 9.2, the Constitution establishes public authorities' obligation to promote the necessary conditions to guarantee real and effective gender equality.

In Spain, gender impact assessments of proposed legislation have become mandatory since the enactment of Law 30/2003 of $13^{\text {th }}$ October. Later, Organic Law 3/2007 established, in article 19, that "projects of general provisions and especially relevant economic, social, cultural and artistic plans that are submitted for approval by the Council of Ministers must include a gender impact assessment" (Collantes \& Sanchís, 2009).

In this paper, we propose that GIE reports be used as a tool for assessing and diagnosing whether a given measure or action will affect men and women equally. Our secondary objectives include: a) presenting a gender diagnostic; and b) propose measures which 
will help close the gender gap, favouring equal opportunity between men and women.

These gender impact assessment reports accompany regulatory and policy projects and allow the estimation of a given project's differential effects on men and women. This in turn can introduce recommendations that may contribute to fulfilling the goal of equal opportunity, as established in the Equality Law and other applicable legislation.

This topic is of the most importance, given that the gender wage gap has yet to be closed. Despite Spanish women being more qualified than ever before, they do not have the same opportunities as male workers. Access to jobs and promotion within firms are two workplace topics that must be addressed, so that half of the population - the female half - is not ignored.

In Spain, from 2010 to 2014, the percentage of women between 30 and 34 years of age who had obtained some kind of higher education degree was greater than that of men. In 2014, the percentage was $36.8 \%$ of men, while it was $47.8 \%$ for women. In the EU-28, and during the same year, both percentages were lower than in Spain $(33.6 \%$ of men and $42.3 \%$ of women) (Ministry of Education, Culture, and Sport, 2014a).

In every EU-28 country the number of graduate women is higher than the number of graduate men (INE, Eurostat, 2012).

In 2012, the number of Spanish women who had graduated from higher education was $28.1 \%$ higher than the number of men. For that same year, the number of EU-28 women who had graduated from higher education institutions was $43.2 \%$ superior to than that of men.

In 2012, the largest percentage of women completing their higher education programs over the total number of graduates could be found in healthcare and welfare (75.0\%), while in the EU-28 most were graduates in the field of education and training (79.5\%). Meanwhile, the lowest percentages could be found in engineering, manufacturing, and construction, with $26.8 \%$ in Spain and $26.9 \%$ in the EU-28 (INE, Eurostat, 2012).

In 2014, the percentage of Spanish women with higher education aged between 25 and 64 was $36.5 \%$, while for men it was $32.8 \%$ (Ministry of Education, Culture, and Sport, 2014b).

In the fourth quarter of 2015 , female unemployment $(22.52 \%)$ was higher than that of men (19.49\%) (INE, 2015). As we mentioned earlier, women's average yearly salaries are lower than those of men 
and most domestic responsibilities fall upon women. In 2013, part time employment statistics for workers aged between 25 and 54 showed significant disparities between men and women. Only $9.7 \%$ of male workers hold part time jobs, compared with $21.4 \%$ for females. For women, this percentage increases with the number of children, while for men the percentage decreases. The percentage of men with two children who work part-time jobs is $4.8 \%$, while the corresponding percentage of women is $30.4 \%$. Regarding the percentage of workers who have reduced the total number of hours worked to take care of their children, we find the largest disparities in the 25 to 44 age group: $2.00 \%$ of men reduced their number of hours worked by an amount equal or greater than one month, while this same statistic was $21.5 \%$ for women. At the same time, $95.8 \%$ of men did not reduce their work hours and neither did 76.5\% of women (INE, 2010).

Summing up, the data we have presented seems to show that gender discrimination aimed at women continues to exist. For this reason, gender impact analyses are an indispensable analytical tool in our field of research.

Feminist economics must play a key role in proving that equality is a necessary condition for sustainable development that must be seen as an asset, rather than a cost (Pazos, 2009).

\section{METHOD}

In this context, we provide two analyses: first, we analyse the $7^{\text {th }}$ Framework Programme for Research and Technological Development (7FP) and the Horizon 2020 Framework Programme for Research and Innovation (HP2020) from a gender perspective; and, second, we apply GIE to said programs. We will also analyse whether these reports are convenient methodological assessment tools and whether they could be used to detect and act upon existing gender discrimination.

Our study is based on the Royal Decree 1083/2009, of $3^{\text {rd }}$ July, on the regulation of the Regulatory Impact Analysis Reports (State Official Newsletter, BOE No. 173, of $18^{\text {th }}$ July 2009), which goal is to guarantee that there is sufficient information to gauge the impact on the recipients and agents affected during the design and implementation of a given legislative project. RD1083/2009 develops the content of Law 30/2003, of $13^{\text {th }}$ October, on the measures necessary to 
include gender impact assessments into the provisions designed by the Government, alongside the Methodological Guide for the development of the Regulatory Impact Analysis Reports.

Throughout the present paper we have used a variety of qualitative techniques, beginning with our survey of secondary information, academic literature and the qualitative and quantitative documents relevant to the topic at hand.

To use gender impact reports as an assessment tool, we will follow the analytical methodology developed in the Regulatory Impact Analysis Report and, specifically, on the gender impact analysis that our research focuses on. We show how to apply GIE reports to European projects by using gender indicators and, in the next section, we explain how this is applied to our research in more detail.

The analysis studies the results obtained from the application of cross-sectional gender legislation to a research programme and determining the possible impact it may have had in closing the gender wage gap between male and female researchers. We propose four main blocs of content which allow a progressive, logical sequence and guarantee that our analyses are both useful and effective.

1. Initial Situation. A diagnosis of the situation which identifies all possible gender inequalities related to the 7FP and HP2020 fields are applied to and also establishes a connection between the statistical results generated by the application of gender equality policies. To properly describe the starting points we will take into account the qualitative and quantitative indicators.

2. Predicted results. This bloc consists of an a priori forecast of how the application of gender cross-sectional policies like 7FP and HP2020 affect the initial situation as measured by the aforementioned statistical data. The objective is to achieve a direct integration of women into research activities and also their indirect integration into the workforce.

3. Gender Impact Assessment. We evaluate the predicted results, regarding their implications on equality opportunity, and assess whether the policies meet the equality policy's targets. There are three possible scenarios. The first is unfavourable and gender inequalities are not reduced or diminished, therefore implying that the policies' application does not contribute to attaining equality. The second is neutral, in which there are no preexisting inequalities and, given this case, the policy will 
produce no foreseeable changes in this situation. The third is favourable and entails a decrease in the detected inequalities. This, in turn, helps to contribute to the completion of the objectives established by the equal opportunities policy. We apply our qualitative analysis to both 7FP and HP2020. As for the quantitative indicators, we examine each framework programme budget, the number of 7FP signed grant agreements, the EU's contribution to the concluded 7FP calls which closed, between 2007-2013 per specific programme, the number of gender projects financed by $7 \mathrm{FP}$, the number of projects in the Capacities and Cooperation programmes that include reports on gender issues and gender equality, as well as the number of proposals presented and granted by Spaniards in the European Research Council's finance programme in between 2008 and 2012.

4. Proposals of improvement. We suggest measures, such as changes to the wording and content of EU project calls or recommendations on the application of specific rules, to further the goal of closing the gender income gap and improve the results of higher female participation in research and in the workforce. The analysis and assessment of gender impact of European projects should continue to be developed and should be applied to future official calls.

Having presented our main tool, we will now apply it to the gender analysis of 7FP (2007-2013) and HP2020 (2014-2020). In the first case the analysis is ex post, as the framework programme has already been concluded; however, the analysis of HP2020 is of an ex dure nature, as it is still being implemented.

7FP aims to bolster gender equality and states that " $\mathrm{t}]$ he integration of the gender dimension and gender equality will be addressed in all areas of research" (Decision no. 1982/2006/CE of $18^{\text {th }}$ December 2006, OJ L 412, 30/12/2006, p. 1).

This programme incorporates a set of new measures to promote gender equality:

- Active support of initiatives to promote women's role in science. To this end, the 7FP set the target female participation rate at $40 \%$.

- “The equal treatment of men and women's realities as equal parts in research and thereby ensuring the highest scientific 
quality: 'as long as humans participate in research, for example, as consumers, users or patients, or in trial processes, gender is an issue that should be taken into account and dealt with." (Ministry of Science and Innovation; European Commission. Research \& Innovation, 2011).

- Gender, and promoting gender equality, should be included in the research project proposal and should be taken into consideration in every step of the research cycle.

- "As for promoting gender equality, implementing the principles included in the European Charter and the Code of Conduct for the Hiring of Researchers is a good practice (for example, an open and impartial selection process and work conditions and culture that are fair" (Ministry of Science and Innovation; European Commission. Research \& Innovation, 2011).

- "The Orientation Notes for the Negotiation of 7FP also offer specific examples of measures that research teams and universities can adopt to support the commitment to gender equality" (Ministry of Science and Innovation; European Commission. Research \& Innovation, 2011).

- At the end of their projects research teams should be obligated to present the results relating to awareness and the social implications, including the gender aspects, and produce a report on the staff's statistics (Ministry of Science and Innovation; European Commission. Research \& Innovation, 2011).

- Within 7FP, research into gender topics is financed primarily in the "Sciences in Society" area of the Capacities Programme.

The goal of the GIE reports is to determine whether these measures to include gender perspectives into policy design will contribute to balancing male and female participation rates in research and close the existing gender gap. This requires verifying whether, after the implementation of the policy, there are any variations in the initial situation of women. This, in turn, requires that the role of women in the different activities be analysed to detect any and all inequalities with men and that the necessary measures be implemented to correct them. Thus, the policy would contribute to furthering the role of women in research activities.

As for HP2020, gender is a cross-sectional and crucial issue. The Framework Programme pursues three goals, following the EU's 2016-2019 Strategic Engagement for Gender Equality 2016-2019 and the European Research Area (ERA)'s July 2012 communication: 
- Gender balance in decision making: Just as in 7FP, the Commission has set a target of attaining a $40 \%$ participation rate of women in expert groups and evaluation panels. The Horizon 2020 Advisory groups have a target of $50 \%$ for the under-represented sex (European Commission. Research \& Innovation. Science With and For Society: Policy. Gender Equality).

- Gender balance in research teams at all levels: Applicants for funding are encouraged to promote gender balance at all levels of their teams. According to guidelines by the Commission in the Gender Equality in Horizon 2020, the participation of women in the Scientific European Area must be encouraged both as scientists/technologists and within the evaluation, consultation, and implementation processes (European Commission. Research $\&$ Innovation. Science With and For Society: Policy. Gender Equality).

- Integrating gender/sex analysis in research and innovation (R\&I) content: Not only should these be taken into account while determining the composition of research groups, but also in all matters regarding the inclusion of these aspects in the proposed research and innovation themes, when appropriate, and in line with the programme's management (European Commission. Research \& Innovation. Science With and For Society: Policy. Gender Equality).

Activities should also aim at implementation of principles relating to equality between women and men as laid down in Articles 2 and 3 of the Treaty of the European Union (Official Journal of the European Union, $26^{\text {th }}$ October, 2012, No. 326) and in Article 8 of the Treaty on the Functioning of the European Union (Official Journal of the European Union, $26^{\text {th }}$ October, 2012, No. 326).

Gender equality is embedded in every step of the research cycle (European Commission. European Research Area: Gender equality and gender mainstreaming in research), as well as in the advisory groups, respecting the equality of men and women in the composition of the groups. Each group will include at least one gender issues expert with experience in research and innovation and the experts from all groups will meet in an ad hoc formation, General Introduction of the Work Programme. The idea is to introduce balance of men and women into research teams and explicitly integrate this facet through various topics in all sections of the Work Programme. The research proposal's 
documentation must include sections where participants detail gender information, must include the participation of evaluation experts in the assessment process, as well as in the Grant Agreement and Negotiations (art. 33.1 of the mono and multi-beneficiaries Model Grant Agreement). Furthermore, gender will be integrated into monitoring, training among the eligible costs of an action, rules of participation (articles 13, 18 and 40 of Regulation (EU) No. 1290/2013 of the European Parliament and of the Council, of $11^{\text {th }}$ December, 2013, laying down the rules for participation and dissemination in "Horizon 2020 - the Framework Programme for Research and Innovation (2014-2020)" and repealing Regulation (EC) No. 1906/2006. Official Journal of the European Union, of $20^{\text {th }}$ December, No. 347) and there will be a specific call for gender equality within the Science with and for Society Work Programme.

\section{RESULTS}

Next, we apply the methodology described earlier, all four steps, to determine 7FP and HP2020 effects on male and female recipients of the same field.

\section{Initial situation}

According to data on the EU-28, specifically on the number of researchers per one thousand labour force workers, in 2012 there were fewer active female researchers than male ones. The gap, following this same measure, is 5.4 points per every thousand. In Spain this situation repeats itself: although smaller, there is still a gap of 2.6 points. However, the total number of active, female researchers in Spain is slightly higher than that of the EU-28.

Regarding the growth rate of $\mathrm{PhD}$ graduates, between 2008 and 2012 Spain presented significant growth compared to the EU-28. It is worth mentioning that the growth rate for women was higher than for men. As for the compound annual growth rate for researchers, between 2005 and 2011 female researchers were better represented both in Spain and the EU-28.

Both the proportion (expressed as a percentage) of women $\mathrm{PhD}$ graduates and woman researchers show that the number of female 
researchers in Spain was higher than in the EU-28 in 2012. Accounting for the various research fields, in 2012 female researchers made up a larger percentage in "Government" and "Business enterprise" in Spain than in the EU-28. In the "High Sector" the percentages were almost equal. A summary of the data is shown in Table 1.

Table 1. General information (\%)

\begin{tabular}{|l|c|c|c|c|}
\hline & \multicolumn{2}{|c|}{ EU-28 } & \multicolumn{2}{c|}{ Spain } \\
\hline & Female & Male & Female & Male \\
\hline $\begin{array}{l}\text { Researchers per thousand labour force, by sex, } \\
2012\end{array}$ & 7.6 & 13.00 & 7.8 & 10.4 \\
\hline $\begin{array}{l}\text { Compound annual growth rate for researchers, by } \\
\text { sex, 2005-2011 }\end{array}$ & 4.8 & 3.3 & 4.2 & 2.8 \\
\hline Growth rates of PhD graduates, 2008-2012 & 17.49 & 8.68 & 30.14 & 29.58 \\
\hline Proportion (\%) of women PhD graduates, 2012 & 47 & & 49 & \\
\hline Proportion of women researchers, 2012 & 33 & & 38.8 & \\
\hline Proportion of women researchers by sector, 2012 & & & & \\
\hline Higher education & 41 & & 40.8 & \\
\hline Govemment & 41.6 & & 48.5 & \\
\hline Business Enterprise & 19.7 & & 29.4 & \\
\hline
\end{tabular}

Source: Directorate-General of Research, European Commission, She Figures 2015. Gender in Research and Innovation, and own preparation.

In reference to female $\mathrm{PhD}$ graduates, in 2012 they were most underrepresented in the field of "Engineering, manufacturing and construction," both in the EU and in Spain (although Spain had a marginally better percentage). In general, the proportion of Spanish female $\mathrm{PhD}$ graduates is higher in all fields than in the EU-28 (see Table 2).

Table 2. Proportion of female $\mathrm{PhD}$ graduates by broad field of study (\%), 2012

\begin{tabular}{|l|c|c|c|c|c|c|c|c|}
\hline & $\begin{array}{c}\text { Edu- } \\
\text { cation }\end{array}$ & $\begin{array}{c}\text { Huma- } \\
\text { nities } \\
\text { and } \\
\text { arts }\end{array}$ & $\begin{array}{c}\text { Social } \\
\text { sciences, } \\
\text { business } \\
\text { and law }\end{array}$ & $\begin{array}{c}\text { Science, } \\
\text { mathe- } \\
\text { matics and } \\
\text { computing }\end{array}$ & $\begin{array}{c}\text { Engineering, } \\
\text { manufac- } \\
\text { turing and } \\
\text { construction }\end{array}$ & $\begin{array}{c}\text { Agricul- } \\
\text { ture and } \\
\text { veterinary }\end{array}$ & $\begin{array}{c}\text { Health } \\
\text { and } \\
\text { welfare }\end{array}$ & $\begin{array}{c}\text { Ser- } \\
\text { vices }\end{array}$ \\
\hline EU-28 & 64 & 55 & 51 & 42 & 28 & 56 & 59 & 44 \\
\hline Spain & 55 & 52 & 47 & 47 & 30 & 56 & 56 & 30 \\
\hline
\end{tabular}

Source: Directorate-General of Research, European Commission, She Figures 2015. Gender in Research and Innovation, and own preparation. 
In academia, Spanish women make up a higher percentage of the total than their EU-28 counterparts. The highest proportions can be found in Grade D, and the lowest in Grade A, both in Spain and the EU-28 (see Table 3).

Table 3. Proportion of women academic staff (\%), by grade and total, 2013

\begin{tabular}{|l|c|c|c|c|c|}
\hline & Grade A & Grade B & Grade C & Grade D & Total \\
\hline EU-28 & 20.9 & 37.1 & 45.1 & 46.9 & 40.6 \\
\hline Spain & 20.9 & 39.5 & 48.9 & 51.00 & 37.7 \\
\hline
\end{tabular}

Source: Directorate-General of Research, European Commission, She Figures 2015. Gender in Research and Innovation, and own preparation.

As for employment in R\&D (see Table 4), in 2014 the number of men was significantly higher than that of women. This is especially notable in the field of Business, where there are almost twice as many male employees. However, both the Public Administration and the Not for Profit sectors are populated by a greater number of female employees.

Table 4. Personnel employed in R\&D by sector of execution and sex, 2014 (Spain)

\begin{tabular}{|l|c|c|}
\hline & \multicolumn{2}{|c|}{2014} \\
\hline & Female & Male \\
\hline Public administration & $19,758.2$ & 19,006 \\
\hline Higher education & $32.956,9$ & $40,470.8$ \\
\hline Business & $26,992.8$ & $60,649.2$ \\
\hline Not For Profit institutions & 223.9 & 174.8 \\
\hline TOTAL & $79,931.8$ & $120,300.8$ \\
\hline
\end{tabular}

Source: INE (Statistics National Institute).

Focusing on the Spanish government sector, the number of female researchers is less than that of men in 2012 in every field except medical sciences (see Table 5).

Table 5. Number of researchers in Spain in the government sector by field of science and sex, 2012

\begin{tabular}{|l|c|c|c|c|c|c|}
\hline & $\begin{array}{c}\text { Natural } \\
\text { sciences }\end{array}$ & $\begin{array}{c}\text { Engineering } \\
\text { and technology }\end{array}$ & $\begin{array}{c}\text { Medical } \\
\text { sciences }\end{array}$ & $\begin{array}{c}\text { Agricultural } \\
\text { sciences }\end{array}$ & $\begin{array}{c}\text { Social } \\
\text { sciences }\end{array}$ & Humanities \\
\hline Women & 2.395 & 1.723 & 8.769 & 1.572 & 674 & 466 \\
\hline Men & 3.177 & 2.970 & 7.443 & 1.683 & 781 & 539 \\
\hline
\end{tabular}

Source: Directorate-General of Research, European Commission, She Figures 2015. Gender in Research and Innovation, and own preparation. 
The proportion of men employed in university upper-management is significantly higher than that of women. This is especially true in the case of the position of rector, where the difference between men (94\% of rectors) and women (6\% of rectors) is abysmal, and also in that of deans and school management, where there are significantly more men (74.8\%) than women (25.2\%) (See Table 6).

Table 6. Percentage of high responsibility positions at Spanish public universities held by men and women, 2012

\begin{tabular}{|l|c|c|}
\hline \multirow{2}{*}{} & \multicolumn{2}{|c|}{2012} \\
\cline { 2 - 3 } & Female & Male \\
\hline Rectorate & 6.00 & 94.00 \\
\hline Vice-rectorate & 41.8 & 58.2 \\
\hline Deans-School Directors & 25.2 & 74.8 \\
\hline Vicedeans-School Subdirectors & 45.4 & 54.6 \\
\hline
\end{tabular}

Source: Economy and Competitiveness Ministry.

Although the EU has repeatedly cited gender equality as an indispensable foundation of progress, the data we have analysed shows that the mix of policies and measures that have been applied up until now have proven to be insufficient in overcoming gender inequality and gender-based discrimination. This failure is especially apparent when it comes to the government's labour cost reducing policies. These policies typically make it cheaper to fire workers and also reduce the entrance of women into the labour market. Other aspects that are not regulated equally for men and women are the emission of permits and certificates of birth and adoption (Pazos, 2015). These limitations also extend to matters that make it more difficult for women to care for family members. At the same time, public authorities have not and are not promoting the equal division of responsibility between men and women or other measures which would allow society to advance towards true and effective equality, rather than simple legal equality.

If public policies promote spending plans which ignore gender biases and, simultaneously, reduce spending on social programmes, the negative impact falls mainly on women. This is due to the fact that as the supply of government-provided social services (such as care services for children, the elderly, and the sick) falls, the excess demand is usually satisfied within the family unit and, mostly, by women. 
Women who take charge of the so-called "family responsibilities" do not receive financial compensation for their efforts. At the same time, they also receive lower compensation for their job performance because they are forced to divide their time between these responsibilities and paid work. Meanwhile, the Government continues to state that their policies and budgets know no gender.

To achieve full equality between men and women, we must overcome the current political, legal, and cultural patriarchy in which men are raised to play a privileged role in public life, with this privilege traditionally being bestowed upon them by the whole of society, and women are relegated to the private sphere as mere caregivers (Salazar, 2013).

This end makes it necessary to eliminate the idea of masculinity associated with the father figure that has been imposed on society. This idea states that men must conform to a pattern marked by being competitive, physically strong and playing the role of the household head. Thus, they must renounce everything related to emotions and any work related to family care. To achieve this end we must accept that men also have gender and that there is no such thing as a democracy without equality between men and women (Salazar, 2013).

\section{Predicted results}

Our analysis of 7FP will focus on the final results generated by this programme, rather than predictions or intermediate data, because it has already ended.

Beginning with the funds budgeted for each specific programme, we observe that the Capacities programme, which finances most gender studies, receives the least amount of money out of the four pillars that make up 7FP (Cooperation, Ideas, People, and Capacities; see Table 7).

Table 7. 7FP - Specific Programmes

\begin{tabular}{|l|l|l|l|l|}
\hline Cooperation & Ideas & People & Capacities & Euratom \\
\hline 32.413 Million & 7.510 Million & 4.750 Million & 4.097 Million & 2.700 Million \\
\hline Euros & Euros & Euros & Euros & Euros \\
\hline
\end{tabular}

Source: European Commission. Research \& Innovation. 7FP in Brief: Structure of 7FP.

If we focus on the number of proposals that resulted in signed grant agreements, Capacities once again stands out for having the fewest 
number of grants and also receiving the smallest EU contribution of any of the four main groups (see Table 8).

Table 8. Numbers of 7FP signed grant agreements and EU contribution (in $€$, Million) for concluded $7 \mathrm{FP}$ calls with closure dates in the period $2007-2013$ by specific programme

\begin{tabular}{|l|c|c|}
\hline \multicolumn{1}{c|}{$\begin{array}{c}\text { Specific } \\
\text { Programme }\end{array}$} & Grants & $\begin{array}{c}\text { EU } \\
\text { Contribution } \\
(€, \text { Million) }\end{array}$ \\
\hline Cooperation & 7,834 & 28,336 \\
\hline Ideas & 4,525 & 7,673 \\
\hline People & 10,716 & 4,778 \\
\hline Capacities & 2,025 & 3,772 \\
\hline Euratom & 138 & 358 \\
\hline Total & 25,238 & 44,917 \\
\hline
\end{tabular}

Source: Directorate-General for Research and Innovation, European Commission, Seventh 7FP Monitoring Report. Monitoring Report 2013.

We must point out that 7FP financed a total of 21 gender projects and that eleven of them are still ongoing. All of these research projects are framed within 7FP's Science of Society programme (see Table 9).

Table 9. Gender Projects funded by the 7FP

\begin{tabular}{|l|l|}
\hline FP7 ongoing projects & FP7 finished projects \\
\hline 11 & 10 \\
\hline
\end{tabular}

Source: European Commission. Research \& Innovation. Science With and For Society: Policy.

Out of a total of 2,721 completed projects that published a gender aspects report, 667 (25\%) state that they took some form of Gender Equality actions (see Table 10).

Table 10. 7FP Cooperation and Capacities programmes - completed projects (by December 2014) that reported gender aspects and with Specific Gender Equality Actions and Gender Action Types

\begin{tabular}{|l|c|c|}
\hline \multicolumn{1}{|c|}{ Priority Area } & $\begin{array}{c}\text { Projects with a gender aspects } \\
\text { report }\end{array}$ & $\begin{array}{c}\text { Projects with Gender Equality } \\
\text { Actions }\end{array}$ \\
\hline Cooperation & 1,845 & 490 \\
\hline Capacities & 876 & 177 \\
\hline Total & 2,721 & 667 \\
\hline
\end{tabular}

Source: Directorate-General for Research and Innovation, European Commission, Seventh 7FP Monitoring Report. Monitoring Report 2013. 
Focusing on 7FP proposals made by Spanish researchers, and specifically on those financed by the European Research Council (ERC), we find that although women proposed fewer projects than men in every panel, their overall rate of success was mostly equal. We find that women were more successful than men in getting their proposals approved in the Advanced Grants (AdG) panel for Social Sciences and Humanities and the Starting Grants (StG) panels for Life Sciences and Physical Sciences and Engineering (see Tables 11 and 12).

Table 11. Number of proposals presented by male and female Spanish researchers to the European Research Council financing programmes, by panels and sex, 2008-2012

\begin{tabular}{|l|c|c|c|c|c|c|}
\hline & \multicolumn{3}{|c|}{ Advanced Grants (AdG) } & \multicolumn{3}{c|}{ Starting Grants (StG) } \\
\hline & $\begin{array}{c}\text { Life } \\
\text { Sciences }\end{array}$ & $\begin{array}{c}\text { Physical } \\
\text { Sciences and } \\
\text { Engineering }\end{array}$ & $\begin{array}{c}\text { Social } \\
\text { sciences and } \\
\text { Humanities }\end{array}$ & $\begin{array}{c}\text { Life } \\
\text { Sciences }\end{array}$ & $\begin{array}{c}\text { Physical } \\
\text { Sciences and } \\
\text { Engineering }\end{array}$ & $\begin{array}{c}\text { Social } \\
\text { sciences and } \\
\text { Humanities }\end{array}$ \\
\hline Women & 32 & 14 & 61 & 180 & 83 & 91 \\
\hline Men & 210 & 252 & 125 & 313 & 429 & 142 \\
\hline
\end{tabular}

Source: Economy and Competitiveness Ministry (2014).

Table 12. Number of grants to Spanish men and women evaluated by the European Research Council, by panel and sex, 2008-2012

\begin{tabular}{|l|c|c|c|c|c|c|}
\hline & \multicolumn{3}{|c|}{ Advanced Grants (AdG) } & \multicolumn{3}{c|}{ Starting Grants (StG) } \\
\hline & $\begin{array}{c}\text { Life } \\
\text { Sciences }\end{array}$ & $\begin{array}{c}\text { Physical } \\
\text { Sciences and } \\
\text { Engineering }\end{array}$ & $\begin{array}{c}\text { Social } \\
\text { sciences and } \\
\text { Humanities }\end{array}$ & $\begin{array}{c}\text { Life Sci- } \\
\text { ences }\end{array}$ & $\begin{array}{c}\text { Physical } \\
\text { Sciences and } \\
\text { Engineering }\end{array}$ & $\begin{array}{c}\text { Social } \\
\text { sciences and } \\
\text { Humanities }\end{array}$ \\
\hline Women & 3 & 0 & 6 & 12 & 10 & 4 \\
\hline Men & 23 & 26 & 11 & 20 & 42 & 10 \\
\hline
\end{tabular}

Source: Economy and Competitiveness Ministry (2014).

As for HP2020, we begin our analysis by observing the amount of funds budgeted for each specific programme. The "Science for Society" programme, which is where proposals for gender studies are submitted, is grouped together with a variety of other programmes under the category "Other," from which we can deduce that that these projects received less financing than the other three main pillars of HP2020 (Excellent Science, Industrial leadership, and Societal Challenges; see Table 13). 
Table 13. Horizon 2020 - Specific Programmes

\begin{tabular}{|l|l|l|l|l|l|}
\hline $\begin{array}{l}\text { Excellent } \\
\text { science }\end{array}$ & $\begin{array}{l}\text { Industrial } \\
\text { leadership }\end{array}$ & $\begin{array}{l}\text { Societal } \\
\text { challenges }\end{array}$ & $\begin{array}{l}\text { European Institute } \\
\text { of Innovation and } \\
\text { Technology (EIT) }\end{array}$ & Other & Euratom \\
\hline $\begin{array}{l}\text { EUR 24,4 } \\
\text { billion }\end{array}$ & $\begin{array}{l}\text { EUR 17,0 } \\
\text { billion }\end{array}$ & $\begin{array}{l}\text { EUR 29,7 } \\
\text { billion }\end{array}$ & EUR 2,7 billion & $\begin{array}{l}\text { EUR 3,2 } \\
\text { billion }\end{array}$ & $\begin{array}{l}\text { EUR 1,6 } \\
\text { billion }\end{array}$ \\
\hline
\end{tabular}

Source: European Commission. 2013. Factsheet: Horizon 2020 budget.

HP2020's policy on integrating the gender dimension in research content, which pushes to increase diversity in the composition of research teams, aims to improve the results generated by projects. To promote women's entrance into the various research specialties, HP2020 has set a target female participation rate of at least $40 \%$ and hopes that this measure leads to more equal opportunities for male and female researchers.

In light of the measures that we have described, we can expect that the current situation of equal opportunity in research and development to improve:

- In terms of absolute participation of men and women;

- In terms of the participation of men and women in the various specialties.

\section{Gender impact assessment}

Despite the EU's gender strategies and policies, the European Commission is committed to promoting gender equality in research and innovation (R\&I). It is part of the Commission's Strategic engagement for gender equality in all EU policies for the period 2016-2019. In addition, the EU has a well-established regulatory framework on gender equality, including binding Directives, which apply widely across the labour market including the research sector. European research still suffers from a considerable loss of human capital because of its inefficient use of highly qualified women. In 2012, Spain had a total of 4,064 female $\mathrm{PhD}$ graduates, and the EU-28 had 56,652 (Directorate-General of Research, European Commission, She Figures 2015), numbers that only show minor differences when compared to those of men. Between 2008 and 2012, the growth rate of the number of female $\mathrm{PhD}$ candidates was higher than that of men. However, results show that men outnumber women in R\&D employment numbers and that universities' highest positions, such as rector or dean, are also male 
dominated. In the case of rectors, the difference between the number of men and women is especially significant.

Both 7FP and HP2020 provide less funding to research on gender related projects than to projects on other matters. Consequently, the number of proposals that result in the signing of a grant agreement is also lower for gender related projects. Additionally, if we take into account the gender specific projects that were financed, we find that there are only twenty one.

Our analysis of the Cooperation and Capacities programmes shows that out of 2,721 projects with gender aspects reports, only $25 \%$ incorporated gender equality measures and actions.

As for the number of proposals presented to 7FP through the ERC's Starting Grants and Advanced Grants financing programmes, men once again outnumbered women in 2012. In general, the success rates, understood as the proportion of granted proposals, were nearly the same for both sexes; however, women achieved higher rates in the Advanced Grants' Social Sciences and Humanities panel and in the Starting Grants' Science of Life and Physical Sciences and Engineering panels.

This leads us to qualify the programmes' results as negative. Despite already taking gender perspectives into account, the outcomes of these two financing frameworks have not eliminated gender inequality nor have they closed the existing gender gap.

This raises certain questions, such as why don't women propose more projects, or why don't they make it to universities' highest positions, even though they are equally or more qualified than men. A possible cause could be the way they divide their time. Managing domestic affairs and taking care of the family, as housewives do, may lead many highly qualified women to abandon their professional careers permanently. This translates into an irretrievable loss, both for them and for the society, and could be mitigated if action was taken to harness the caretaking capabilities of men (Pazos, 2009). The problem is in how time is distributed; if this parameter, together with the values that determine the distribution of household chores and family care between the sexes, does not change, the result will be a higher intensity of unpaid work which will mainly affect women (Torres \& Gàlvez, 2009). 


\section{Proposals of improvement}

It is worth mentioning that neither 7FP nor HP2020 include any measures or policies that imply changes allowing for the better organisation of family and work life for men or women. Neither does it contain any that would reduce the risks that men and women face of being excluded from cohabitation, certain domestic activities and some levels of responsibility. Therefore, actions that focus on these issues must be taken.

It is very important that we close the gender gap and there are currently a variety of influential factors that are not being addressed at any level. Among other measures, it is necessary to promote female participation in research and development activities, not only as members of research teams, but also as project leaders.

Gender aspects should be highlighted and should be presented clearly in all major databases. Just as when we search for a given project we are usually presented with basic information on its content, goals, etc., we should also be able to easily find the project's gender data.

As for the amount of funds allocated to HP2020's Science in the Society programme, which includes a call specifically for gender studies, it should be increased. Only 462 million Euros were budgeted for this programme, which represents only $0.60 \%$ of the total budget (European Commission. 2013. Factsheet: Horizon 2020 budget, 2013).

Although the latest publication of "She Figures" shows that there has been limited progress, gender inequality continues to exist at the highest levels of the scientific community. The most recent data indicates that women made up $47 \%$ of $\mathrm{PhD}$ graduates in the EU-28, but made up only $33 \%$ of researchers and $21 \%$ of top-level researchers (grade A). It is even lower at the level of heads of institutions, where a mere $20 \%$ are women. This proves that it is necessary to take additional measures to increase the presence of women in research and overcome the existing gender gap.

The political and economic measures should aim to eliminate the existing differences between men and women. It is obvious that a modern society cannot properly develop without the potential, intellectual, and human resources that women provide. Therefore, public policies should be oriented at increasing their participation and creating an egalitarian model of society that benefits all members of the society. 


\section{DISCUSSION \& CONCLUSIONS}

Our most relevant contribution is the ex post and ex dure analysis of 7FP and HP2020 based on the GIE methodology, which has lead us to the following discussions and conclusions:

Although 7FP and HP2020 both include gender perspectives in their design, the results show that they have failed in their goals of modifying the relationship between men and women researchers and eliminating stereotypes affecting certain fields of research, allowing inequality to continue existing.

As we have shown in this study, 7FP includes a variety of actions and measures to tackle the gender issue. HP2020 takes these measures a step further and emphasises their goals: gender equality in scientific careers, gender balance in decision making, and integration of the gender dimension into the content of research and innovation. This added effort may be a consequence of 7FP's lacking gender perspective or perhaps because of its less than favourable performance on gender issues.

The outlays that 7FP and HP2020 designated for the programmes that include research projects on gender issues were smaller than all others. In other words, research into gender studies was at a disadvantage from the very start.

$7 \mathrm{FP}$ requires research teams to present their results relating to the social implications and awareness, including gender issues, of their projects, as well as a report based on the staff's demographics. We have shown that there were 2,721 projects with gender aspect reports in the Cooperation and Capacities programme. However, only $25 \%$ of these included actions to promote gender equality. It should be made easier to access the data contained in these reports and they should be available on all of the programmes' databases. We also find discrimination against gender statistics when we compare them with other topics, such as financing, partners, etc. We must emphasise that although there are many women with equal or higher qualifications, men still dominate high-level positions and lead most 7FP projects. For example, men lead a majority of ERC programs. However, even though the absolute number of total projects proposed by female researchers is relatively smaller than the number presented by men, their success rate is almost equal and in some panels it is even higher. We deduce 
from this that the presence of female researchers on a given project improves its final evaluation.

We highlight the inefficient use of human capital that is currently taking place in the field of research. There are highly qualified women who do not have access to the same opportunities as men, neither when it comes to entering the research labour market nor when it comes to receiving promotions.

It is necessary to progress towards a society in which socially necessary activities are tackled and completed equally by men and women and also that the benefits of these actions be shared equally. To achieve this goal it is necessary for public administrations to take into account the results generated by studies like ours so that they may properly assess how a given policy will affect existing gender relations. It is our belief that gender democracy should be one of the public administrations' priorities, as well as developing a more transparent system of management, and that by meeting these goals, the benefits they imply will be shared by all future generations.

\section{REFERENCES}

Calvo, A. (2008). La igualdad real en el trabajo aún no existe en nuestro país. Mujerhoy.com. [Online] Retrieved from: http://www.mujerhoy.com/trabajo/ conciliacion/igualdad,real,trabajo,existe,64551,10,2008.html, access date: October 31st, 2016.

Collantes, B., \& Sanchis, A. (2009). La evaluación del impacto de género en la normativa estatal y andaluza. Jaén: Instituto de Estudios Giennenses.

Directorate-General for Research and Innovation (2013). Seventh 7FP Monitoring Report. Monitoring Report 2013. [Online] Retrieved from: http://ec.europa. eu/research/evaluations/pdf/archive/fp7_monitoring_reports/7th_fp7_monitoring_report.pdf, access date: October 31 2016.

Directorate-General of Research, European Commission (2015). She Figures 2015. Gender in Research and Innovation. [Online] Retrieved from: https://ec.europa.eu/research/swafs/pdf/pub_gender_equality/she_figures_2015-final.pdf, access date: October 31st, 2016.

Economy and Competitiveness Ministry. Women and Science Unit (2014). Statistics and Indicators on Gender (in)Equality in Education and Scientific Profession. [Online] Retrieved from: http://www.idi.mineco.gob.es/stfls/MICINN/Ministerio/ FICHEROS/UMYC/Cientificas_cifras_2013.pdf, access date: October 31st, 2016. 
European Commission (2008). The Gender Challenge in Research Funding - Assessing the European National Scenes. [Online] Retrieved from: https://ec.europa.eu/ research/swafs/pdf/pub_gender_equality/gender-challenge-in-research-funding_en.pdf, access date: October $31^{\text {st }}, 2016$.

European Commission (2013). Factsheet: Horizon 2020 Budget. [Online] Retrieved from: http://ec.europa.eu/research/horizon2020/pdf/press/fact_sheet_on_horizon2020_budget.pdf, access date: October $31^{\text {st }}, 2016$.

European Commission (2014). Gender Equality in Horizon 2020. [Online] Retrieved from: http://ec.europa.eu/research/participants/data/ref/h2020/grants_manual/ hi/gender/h2020-hi-guide-gender_en.pdf, access date: October 31 ${ }^{\text {st }}, 2016$.

European Commission (2015). Strategic Engagement for Gender Equality 2016-2019.

[Online] Retrieved from: http://ec.europa.eu/justice/gender-equality/files/ documents/160111_strategic_engagement_en.pdf, access date: October $31^{\text {st }}, 2016$.

European Commission. European Research Area. Gender Equality and Gender Mainstreaming in Research [Online] Retrieved from: http://ec.europa.eu/ research/era/gender-equality-and-gender-mainstreaming_en.htm (access: October $\left.31^{\text {st }}, 2016\right)$.

European Commission. Research \& Innovation. Science With and For Society. [Online] Retrieved from: http://ec.europa.eu/research/swafs/index.cfm (access: October $\left.31^{\text {st }}, 2016\right)$.

European Union. Treaty of the European Union. Official Journal of the European Union, $26^{\text {th }}$ of October 2012 , no. 326.

De Villota, P., Jubeto Y. \& Ferrari, I. (2009). Estrategias para la integración de la perspectiva de género en los presupuestos públicos. Instituto de la Mujer, 19-60. [Online] Retrieved from:

http://www.inmujer.gob.es/observatorios/observIgualdad/estudiosInformes/docs/017-estrategia.pdf, access date: October $31^{\text {st }}, 2016$.

Gabarró, D. (2011). Transformar a los hombres: un reto social. Lleida: Boira, 95-114. Ley 30/2003, de 13 de octubre de 2003, sobre medidas para incorporar la valoración del impacto de género en las disposiciones normativas que elabore el Gobierno. Boletín Oficial del Estado. Madrid, 14 de octubre de 2003, núm. 246.

Ley orgánica 3/2007, de 22 de marzo de 2007, para la igualdad efectiva de mujeres y hombres. Boletín Oficial del Estado. Madrid, 23 de marzo de 2007, núm. 71. Ministry of Education, Culture and Sport (2014a). Education Indicators of the 2020 European Strategy. [Online] Retrieved from: http://www.ine.es/ss/Satellite?L=es_ES\&c=INESeccion_C\&cid=1259925481089\&p=1254735110672 \&pagename=ProductosYServicios\%2FPYSLayout\&param3=1259924822888, access date: October $31^{\text {st }}, 2016$. 
Ministry of Education, Culture and Sport (2014b). Level of Education of the Population. [Online] Retrieved from: https://www.educacion.gob.es/ educabase/tabla.do?sel_1=2\&busc_1=\&cri1=01\&cri1=02\&sel_2=1\&busc_2 $=\&$ cri $2=09 \&$ sel_3 $=3 \&$ busc_ $3=\&$ cri $3=00 \&$ cri $3=01 \&$ cri $3=02 \&$ sel_ $4=1$ \&busc $\_4=\&$ cri $4=10 \&$ rows $=$ sexo\&rows $=$ pa $\%$ EDs\&columns $=$ nivel + de + formaci\%F3n\&columns $=\mathrm{a} \% \mathrm{~F} 10 \&$ numCri $=4 \&$ NumCeldas $=6 \&$ type $=$ pcaxis \&path=\%2FFormacionyml $\% 2$ FEPA $2014 \% 2$ FNivFor $\% 2 F l 0 \% 2 F \&$ file $=$ Niv For03.px\&divi=\&per=\&idtab=\&accion=html, access date: October $31^{\text {st }}, 2016$. Ministry of Finance and Public Administration (2009). Methodological Guide for the Development of the Memory of Regulatory Impact Analysis. [Online] Retrieved from: http://www.seap.minhap.es/dms/es/web/areas/modernizacion-procedimientos/impacto_normativo/guia-metodologica-ain-1264084813.pdf, access date: October $31^{\text {st }}, 2016$.

Ministry of Science and Innovation. European Commission Research \& Innovation (2011). Manual Gender in Research. [Online] Retrieved from: http://www.idi. mineco.gob.es/stfls/MICINN/Investigacion/FICHEROS/El_genero_en_la_investigacion.pdf, access date: October 31 ${ }^{\text {st }}, 2016$.

ONU Women (2015). The Progress of Women in the World 2015-2016: Summary. Transforming Economies for Rights. [Online] Retrieved from: http:// progress.unwomen.org/en/2015/pdf/SUMMARY_ES.pdf, access date: October $31^{\text {st }}, 2016$.

Pazos, M. (2009). El papel de la igualdad de género en la solución de la crisis económica y en el cambio a una economía sostenible. Madrid: Instituto de Estudios Fiscales.

Pazos, M. (2015). Contra la discriminación por maternidad: ¡Paternidad!, Agenda Pública. [Online] Retrieved from: http://agendapublica.es/contra-la-discriminacion-por-maternidad-paternidad/, access date: October 31 2016.

Real Decreto 1083/2009, de 3 de Julio de 2009, por el que se regula la memoria del análisis de impacto normativo. Boletín Oficial del Estado. Madrid, 18 de julio de 2009, núm. 173.

Regulation (EU) no. 1290/2013 of the European Parliament and of the Council, of 11 December 2013, laying down the rules for participation and dissemination in "Horizon 2020 - the Framework Programme for Research and Innovation (2014-2020)" and repealing Regulation (EC) no. 1906/2006. Diario Oficial de la Unión Europea, de 20 de Diciembre de 2013, núm. 347.

Salazar, O. (2013). Masculinidades y ciudadanía. Los hombres también tenemos género. Madrid: Dykinson, S.L.

Sanchis, A. (2012). Epistemología, Feminismo y Género: Investigando sin Complejos. [Online] Retrieved from: https://www.google.es/search?q=Epistemolog\% 
$\mathrm{C} 3 \% \mathrm{ADa} \% 2 \mathrm{C}+$ feminismo+y+g\%C3\%A9nero\%3A+Investigando+sin+complejos\&ie=utf-8\&oe=utf-8\&client=firefox ab\&gfe_rd=cr\&ei=4tqAV_yjJrOp8wfNl7uoDQ, access date: October 31 ${ }^{\text {st }}, 2016$.

Sanchis, A. (2015). Interpretación jurídica, igualdad y género en los estudios de derecho. Aportaciones epistémicas y feministas. Revista General de Derecho Constitucional, IUSTEL, núm. 21, pp. 1-75.

Statistics National Institute (2010). Active Population Survey. Reconciling Work and Family Life. [Online] Retrieved from: http://www.ine.es/prensa/np663. pdf, access date: October $31^{\text {st }}, 2016$.

Statistics National Institute (2012). Education and Training Statistics. Eurostat. [Online] Retrieved from: http://www.ine.es/ss/Satellite?L=es_ES$\& c=I N E S e c c i o n \_C \& c i d=1259925481157 \& p=1254735110672 \& p a-$ gename=ProductosYServicios\%2FPYSLayout\&param3=1259924822888, access date: October $31^{\text {st }}, 2016$.

Statistics National Institute (2013a). Average Annual Salary by Sector of Economic Activity and Period. [Online] Retrieved from: http://www.ine.es/jaxiT3/Datos. htm?t=10911, access date: October $31^{\text {st }}, 2016$.

Statistics National Institute (2013b). Annual Salary Structure Survey. [Online] Retrieved from: http://www.ine.es/prensa/np916.pdf, access date: October 31st, 2016.

Statistics National Institute (2015). Unemployment Rates by Different Age Groups, Sex and Autonomous Community. [Online] Retrieved from: http://www.ine. es/jaxiT3/Tabla.htm?t=4247, access date: October 31 ${ }^{\text {st }}, 2016$.

Torres, J. \& Gálvez, L. (2009). La crisis económica y sus alternativas: una perspectiva de género. In: J. Torres (ed.), Feminismo ante la crisis, Madrid, España: Forum de Políticas Feministas, p. 11.

United Nations, A/CONF.177/20/Rev.1., Report of the Fourth World Conference on Women, Beijing, from the 4th to the 15th of September 1995, New York, 1996. [Online] Retrieved from: http://www.un.org/womenwatch/daw/beijing/ pdf/Beijing\%20full\%20report\%20S.pdf, access date: October 31st, 2016. 


\section{OCENA EUROPEJSKIEJ POLITYKI W DZIEDZINIE BADAŃ, ROZWOJU I INNOWACJI W HISZPANII Z PERSPEKTYWY $\mathrm{PkCl}$}

\section{Abstrakt}

Tło badań. Raporty dotyczące Oszacowania Wpływu Płci (GIE) są idealnym narzędziem do oceny europejskiej polityki dotyczącej badań i rozwoju oraz innowacyjności w Hiszpanii z perspektywy płci.

Cel badań. Podstawowym celem tego badania jest dalsze korzystanie z raportów GIE jako narzędzia do diagnozowania, czy dany środek lub polityka wpłynie na kobiety i mężczyzn w równym stopniu. Nasze cele drugorzędne sa następujące: a) przedstawienie diagnostyki płci; b) zaproponowanie środków i strategii, które pomogą zamknąć istniejące rozbieżności między płciami, i promowanie równych szans dla kobiet i mężczyzn.

Metodologia. Metodologicznie narzędzie to zostanie wykorzystane do analizy działań podjętych w ramach Siódmego Programu Ramowego oraz Pierwszego Programu Horyzont 2020. Zaczynamy, analizując rozwój prawodawstwa w dziedzinie równości płci w Hiszpanii. Druga część naszej pracy dostosowuje raporty GIE jako narzędzie do oceny i diagnozowania europejskich projektów badawczych i innowacyjnych.

Kluczowe wnioski. To dostosowanie to najważniejszy wkład naszej pracy, ponieważ pozwala na analizę polityki dotyczącej publicznych badań i rozwoju oraz innowacji z perspektywy płci. System ten może przyczynić się do tworzenia bogactwa i wzrostu gospodarczego, ponieważ pozwala na to, aby wkład mężczyzn i kobiet był odpowiednio ceniony z perspektywy równości szans.

Słowa kluczowe: polityka innowacji, płeć, GIE. 